\title{
Pengembangan Aplikasi Pembelajaran Matematika Berbasis Android Dengan Pendekatan Kontekstual Pada Materi Persamaan Garis Lurus Untuk Peserta Didik Kelas VIII
}

\author{
Makmuri $^{1}$, Dwi Antari Wijayanti ${ }^{2}$, Ellis Salsabila ${ }^{3}$, Rena Nur Fadillah ${ }^{4}$ \\ 1, 2,3,4 Program Studi Pendidikan Matematika, Fakultas Matematika dan Ilmu Pengetahuan Alam, Universitas Negeri Jakarta, \\ Jl. R. Mangun Muka Raya, RT.11/RW.14, Rawamangun, Kec. Pulo Gadung, Kota Jakarta Timur, Daerah Khusus Ibukota \\ Jakarta 13220 \\ makmuri@unj.ac.id
}

\begin{abstract}
This research aims to develop learning media in the form of android-based mathematical learning applications on straight-line equation material using contextual approaches. This research is a research and development that refers to addie model (Analysis, Design, Development, Implementation, and Evaluation). This application product is tested to students of grade VIII SMP Negeri 7 Jakarta. The resulting product is a mathematical learning application of straightline equation material. The results of this study showed that android-based learning applications can be developed properly as one of the sources of mathematics learning for the process of learning mathematics, especially in straight line equations because it reaches a percentage of $95.65 \%$ when tested into large groups which means very good.
\end{abstract}

Keywords: Mathematics Learning Applications, Contextual Approaches

\begin{abstract}
Abstrak
Penelitian ini bertujuan untuk mengembangkan media pembelajaran berupa aplikasi pembelajaran matematika berbasis android pada materi persamaan garis lurus dengan menggunakan pendekatan kontekstual. Penelitian ini merupakan penelitian dan pengembangan yang mengacu pada model ADDIE (Analysis, Design, Development, Implementation, dan Evaluation). Produk aplikasi ini diujicobakan ke peserta didik kelas VIII SMP Negeri 7 Jakarta. Adapun produk yang dihasilkan berupa aplikasi pembelajaran matematika materi Persamaan Garis Lurus. Hasil penelitian ini menunjukan bahwa aplikasi pembelajaran berbasis android dapat dikembangkan secara layak sebagai salah satu sumber berlajar matematika bagi proses pembelajaran matematika, khususnya pada materi Persamaan Garis Lurus karena mencapai persentase 95,65\% ketika diujicobakan ke dalam kelompok besar yang berarti sangat baik.
\end{abstract}

Kata kunci: Aplikasi Pembelajaran Matematika, Pendekatan Kontekstual

Copyright (c) 2021 Makmuri, Dwi Antari Wijayanti, Ellis Salsabila, Rena Nur Fadillah $\triangle$ Corresponding author: Rena Nur Fadillah

Email Address: renanurfadillah_3115150785@mhs.unj.ac.id (Jl. R. Mangun Muka Raya, RT.11/RW.14, DKI Jakarta)

Received 26 Februari 2021, Accepted 17 Maret 2021, Published 20 Maret 2021

\section{PENDAHULUAN}

Perkembangan dunia abad ke-21 ditandai dengan pemanfaatan teknologi, informasi dan komunikasi dalam segala aspek kehidupan, termasuk dalam proses pembelajaran. Abad ke-21 merupakan abad pengetahuan, zaman dengan akses informasi banyak tersebar dan informasi pun mudah diperoleh (Daryanto \& Karim, 2017). Salah satu hasil dari kemajuan teknologi adalah ponsel serta banyak masyarakat saat ini memakai ponsel yang berbasis smartphone (telepon pintar). Kemajuan teknologi membuat ponsel yang awalnya hanya digunakan sebagai alat komunikasi kini dapat digunakan untuk media sosial, media hiburan, dan bahkan digunakan dalam pembelajaran di sekolah. Sejalan dengan hal tersebut, peneliti mengadakan penyebaran angket yang dilakukan pada tanggal 7 Januari 2019 di kelas VIII.B SMP Negeri 7 Jakarta diperoleh data bahwa peserta didik menggunakan smartphone hanya untuk bermain game dan membuka media sosial saja. Selanjutnya dari hasil 
penyebaran angket yang dilakukan juga menunjukkan bahwa terbatasnya media dan sumber belajar serta kurangnya minat dan motivasi merupakan salah satu penyebab peserta didik kesulitan dalam belajar matematika.

Media pembelajaran didefinisikan sebagai alat bantu proses pembelajaran yang disajikan dari guru kepada peserta didik. Alat bantu pembelajaran yang dibuat guru diubah ke bentuk textbook, komputer, dan lain-lain. Alat bantu pembelajaran ini merupakan klasifikasi dari media pembelajaran (Reiser, 2001). Salah satu pemanfaatan android yaitu sebagai media pembelajaran. Menurut (Safaat, 2015) android merupakan sistem operasi perangkat smartphone berbasisi linux yang mencakup operasi sistem, middleware dan aplikasi. Android juga bersifat open source dan dapat diinstal dengan mudah di setiap perangkat yang sesuai (Setyadi, 2017). Android juga merupakan sistem operasi tercepat serta selalu terbaru dalam merilis versinya dan merupakan sistem operasi hasil modifikasi kernel linux yang sudah terkenal. Dengan berbagai kemudahan yang ada pada android, menjadikan android cepat dikenal dan populer di kalangan pengguna smartphone (Mulyana \& Islandscript, 2012). Berdasarkan penelitian yang dilakukan (Nugroho \& Purwati, 2015) bahwa media pembelajaran dengan sistem operasi android pada penelitian ini dinyatakan valid, berdasarkan beberapa validasi yang ditetapkan oleh orang yang ahli atau pakar dibidangnya.

Smartphone dapat dimanfaatkan dalam pembelajaran matematika untuk membuat peserta didik lebih termotivasi dalam belajar. Hal ini didukung pula oleh hasil wawancara peserta didik kelas VIII.B SMP Negeri 7 Jakarta yang mengatakan bahwa pembelajaran matematika masih dianggap sulit dan membosankan, sehingga dalam memahami materi matematika diperlukan media dan sumber belajar yang tepat sesuai dengan perkembangan saat ini. Melalui pemanfaatan smartphone diharapkan peserta didik lebih tertarik dalam pembelajaran matematika dan membuat pembelajaran matematika lebih bermakna. Media pembelajaran yang sesuai dengan perkembangan zaman diharapkan dapat memberikan perubahan dalam diri peserta didik untuk belajar dalam hal ini khususnya pembelajaran matematika. Hasil angket menyatakan bahwa $40 \%$ peserta didik memilih media pembelajaran yang dapat menyajikan materi matematika yang berkaitan dengan kehidupan sehari-hari, oleh karena itu pendekatan pembelajaran yang sesuai ialah menggunakan pendekatan kontekstual. Pendekatan kontekstual merupakan pendekatan yang mengaitkan materi yang dipelajari dengan kehidupan dunia nyata baik dalam lingkungan sekolah, keluarga maupun masyarakat untuk mampu menemukan makna materi tersebut (Komalasari, 2011). Pendekatan kontekstual dapat diterapkan dalam aplikasi smartphone karena pembelajaran kontekstual dapat diterapkan dalam pembelajaran tatap muka maupun pembelajaran yang termuat dalam suatu media pembelajaran (Gafur, 2003). Adapun terdapat tujuh aspek pendekatan kontekstual meliputi: konstruktivisme, inkuri, bertanya, masyarakat belajar, pemodelan, refklesi dan penilaian yang sebenarnya.

Selanjutnya, peneliti juga melakukan penyebaran angket untuk mengetahui materi yang dianggap sulit oleh peserta didik dan bisa dikembangkan dengan smartphone. Hasil penyebaran angket menunjukkan bahwa materi yang diperlukan oleh peserta didik untuk menggunakan smartphone ialah 
materi persamaan garis lurus. Hal ini sejalan pula dengan hasil wawancara dengan beberapa peserta didik kelas VIII.B yang mengatakan bahwa pada materi persamaan garis lurus banyak ditemukan rumus dan konsep yang sulit dipahami oleh peserta didik dan berakibat salah dalam penerapannya. Selain itu, berdasarkan penelitian yang dilakukan (Umam, Suryawati, \& Septiana, 2017) bahwa kesulitankesulitan peserta didik dalam materi Persamaan Garis Lurus meliputi: 1) Menentukan gradien dari persamaan garis yang diketahui, 2) Menentukan gradien dari satu garis yang sejajar dan tegak lurus, 3) Menentukan persamaan garis lurus dari satu titik dan diketahui gradiennya dan 4) Menentukan langkahlangkah yang sesuai dari soal yang disajikan. Kemudian berdasarkan penelitian yang dilakukan (Sudiono, 2017 ) bahwa dalam menyelesaikan masalah yang terkait dengan persamaan garis lurus, peserta didik masih melakukan beberapa kesalahan yang meliputi: kesalahan dalam memahami soal, kesalahan ketrampilan proses dalam menyelesaikan soal dan kesalahan penulisan jawaban akhir. Oleh karena itu, peserta didik berharap dapat diberikan suatu media pembelajaran yang sesuai dengan materi tersebut.

Berdasarkan hasil angket dan wawancara yang dipaparkan sebelumnya, maka peneliti memilih judul penelitian "Pengembangan Aplikasi Pembelajaran Matematika Berbasis Android dengan Pendekatan Kontekstual pada Materi Persamaan Garis Lurus untuk Peserta Didik Kelas VIII SMP Negeri 7 Jakarta".

\section{METODE}

Penelitian ini termasuk ke dalam penelitian pengembangan dengan menggunakan model ADDIE yang menghasilkan suatu produk berupa aplikasi pembelajaran matematika berbasis android dengan pendekatan kontekstual pada materi Persamaan Garis Lurus. Langkah-langkah penelitian ini mengacu pada model ADDIE menurut (Barnch, 2009) yang memiliki lima tahapan dalam pengembangan produk yaitu Analyze (Analisis), Design (Perancangan), Development (Pengembangan), Implementation (Implementasi), dan Evaluation (Evaluasi). Namun, pada penelitian ini, peneliti hanya melakukan tiga tahapan yang meliputi: Analyze (Analisis), Design (Perancangan), Development (Pengembangan). Subjek pada penelitian ini ialah peserta didik pada kelas VIII. A sebagai kelompok uji coba skala kecil dan kelas VIII. B sebagai kelompok uji coba skala besar. Sebelum diserahkan pada subjek penelitian, produk erleih dahuli diuji kelayakan kepada validator ahli yakni dua validator ahli materi dan bahas, dua validaor ahli media, dan satu guru. Dalam penelitian ini, instrumen penelitian yang digunakan yaitu lembar penilaian kevalidan aplikasi pembelajaran yang telah divalidasi terlebih dahulu kemudian diajukan untuk memvalidasi media serta materi dan Bahasa pada aplik,asi ini. Berikut bagan prosedur pengembangan dapat dilihat pada gambar 1. 


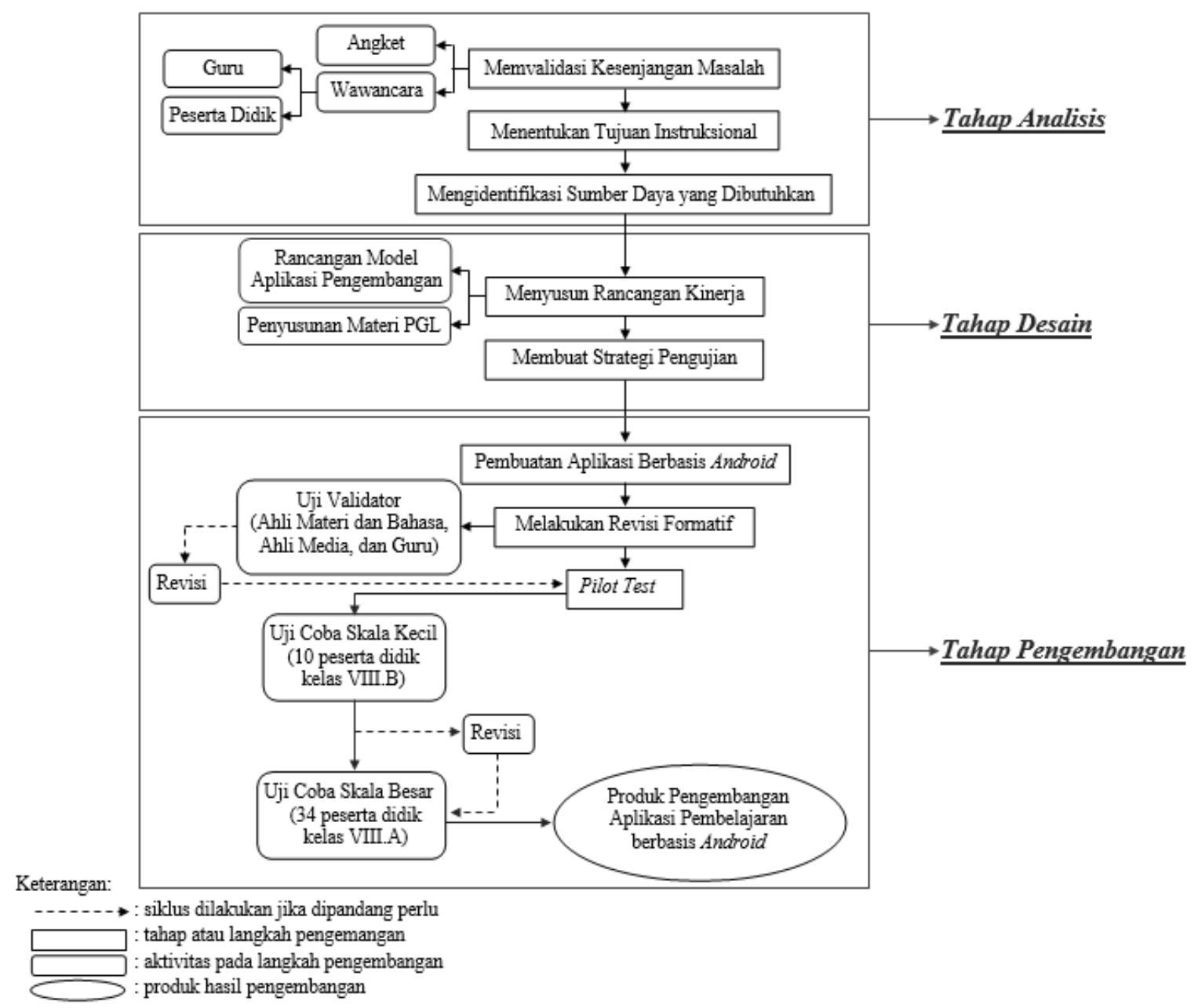

Gambar 1. Prosedur Pengembangan

Instrumen yang digunakan pada subjek dianalisis penelitian menggunakan skala dikotomi dan untuk instrument yang digunakan pada validasi materi dan bahas, validasi media, dan validasi guru dalam penelitian dianalisis menggunakan skala Likert. Instrument dianalisis dengan poin 1 sampai 5. Berikut ini merupakan tabel skala penelitian menurut (Barnch, 2009), disajikan dalam tabel 1.

Tabel 1. Skala Instrumen Penelitian

\begin{tabular}{|c|l|c|c|}
\hline No. & Alternatif Jawaban & Kode & Bobot Skor \\
\hline 1. & Sangat Setuju & SS & 5 \\
\hline 2. & Setuju & S & 4 \\
\hline 3. & Ragu-ragu & R & 3 \\
\hline 4. & Tidak Setuju & TS & 2 \\
\hline 5. & Sangat Tidak Setuju & STS & 1 \\
\hline
\end{tabular}

Data yang diperoleh dari masing-masing selanjutnya diinterpretasikan skornya. Produk dikatan baik jika masing-masing instrumen dalam penelitian ini mencapai presentasi lebih dari $60 \%$ yang berarti masuk dalam kategori baik menurut tabel 2 (Barnch, 2009). 
Pengembangan Aplikasi Pembelajaran Matematika Berbasis Android Dengan Pendekatan Kontekstual Pada Materi Persamaan Garis Lurus Untuk Peserta Didik Kelas VIII, Makmuri, Dwi Antari Wijayanti, Ellis Salsabila, Rena Nur Fadillah

Tabel 2. Interpretasi Skor menurut Buchari dengan Modifikasi

\begin{tabular}{|c|c|}
\hline Presentase & Interpretasi \\
\hline $\mathbf{0} \% \leq \boldsymbol{s k o r} \leq \mathbf{2 0} \%$ & Sangat Kurang \\
\hline $\mathbf{2 0} \%<\boldsymbol{s k o r} \leq \mathbf{4 0} \%$ & Kurang \\
\hline $\mathbf{4 0} \%<\boldsymbol{s k o r} \leq \mathbf{6 0} \%$ & Cukup \\
\hline $\mathbf{6 0} \%<\boldsymbol{s k o r} \leq \mathbf{8 0} \%$ & Baik \\
\hline $\mathbf{8 0} \%<\boldsymbol{s k o r} \leq \mathbf{1 0 0} \%$ & Sangat Baik \\
\hline
\end{tabular}

\section{HASIL DAN DISKUSI}

Peneliti melakukan penelitian dengan model pengembangan ADDIE yang meliputi Analyze, Design, Development, Implementation and Evaluation. Namun pada artikel ini peneliti hanya melakukan penelitian hingga tahap development.

Saat tahap analisa dengan melakukan penyebaran angkat mengenai materi yang dibutuhkan untuk pengembangan media pembelajaran di SMP Negeri 7 Jakarta diperoleh data sebagai berikut

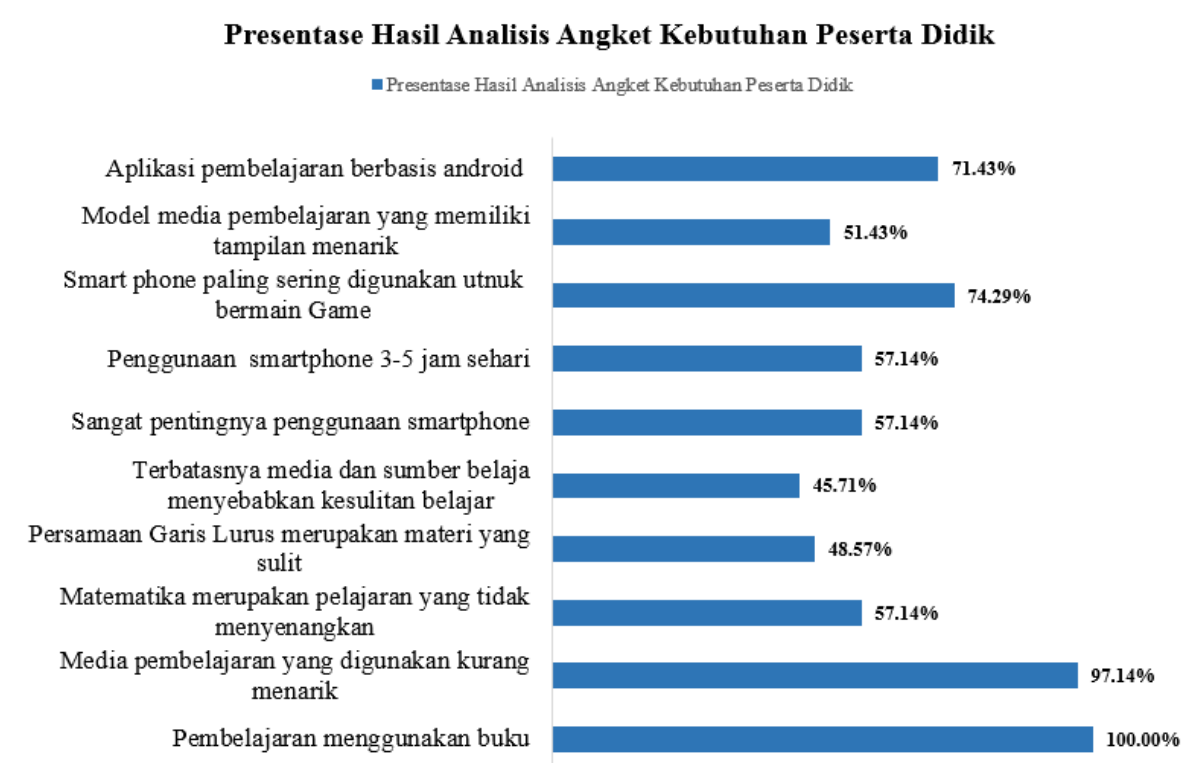

Gambar 2. Diagram Presentase Hasil Analisis Angket Kebutuhan Peserta Didik

Berdasarkan data pada Gambar 2 dapat disimpulkan bahwa pembelajaran masih menggunakan buku yang membuat pembelajaran kurang menarik, matematika masih dianggap sebagai materi yang tidak menyenangkan dan sulit khususnya pada materi Persamaan Garis Lurus, terbatasnya media dan sumber belajar dianggap sebagai sala satu faktor yang menyebabkan peserta didik kesulitan dalam belajar. Selanjutnya peneliti mengidentifikasi sumber daya yang diperlukan dalam penelitian ini. Sumber daya yang dibutuhkan dalam pengembangan aplikasi pembelajaran ialah: 1) berbagai buku dan jurnal tereputasi dalam kurun waktu 10 tahun terakhir tentang aplikasi pembelajaran berbasis android dan pendekatan kontekstual dalam suatu media pembelajaran, 2) sumber daya teknologi yang 
digunakan berupa: laptop, internet, dan software pembuat aplikasi android 3) serta sumber daya manusia (ahli media, ahli materi, guru, dan peserta didik).

Setelah melakukan tahap analisis dan desain, rancangan yang dikembangkan menghasilkan aplikasi pembelajaran matematika berbasis android. Tampilan dari bagian aplikasi pembelajaran disajikan dalam storyboard berikut

Tabel 3. Tampilan Aplikasi Pembelajaran




Pengembangan Aplikasi Pembelajaran Matematika Berbasis Android Dengan Pendekatan Kontekstual Pada Materi Persamaan Garis Lurus Untuk Peserta Didik Kelas VIII, Makmuri, Dwi Antari Wijayanti, Ellis Salsabila, Rena Nur Fadillah

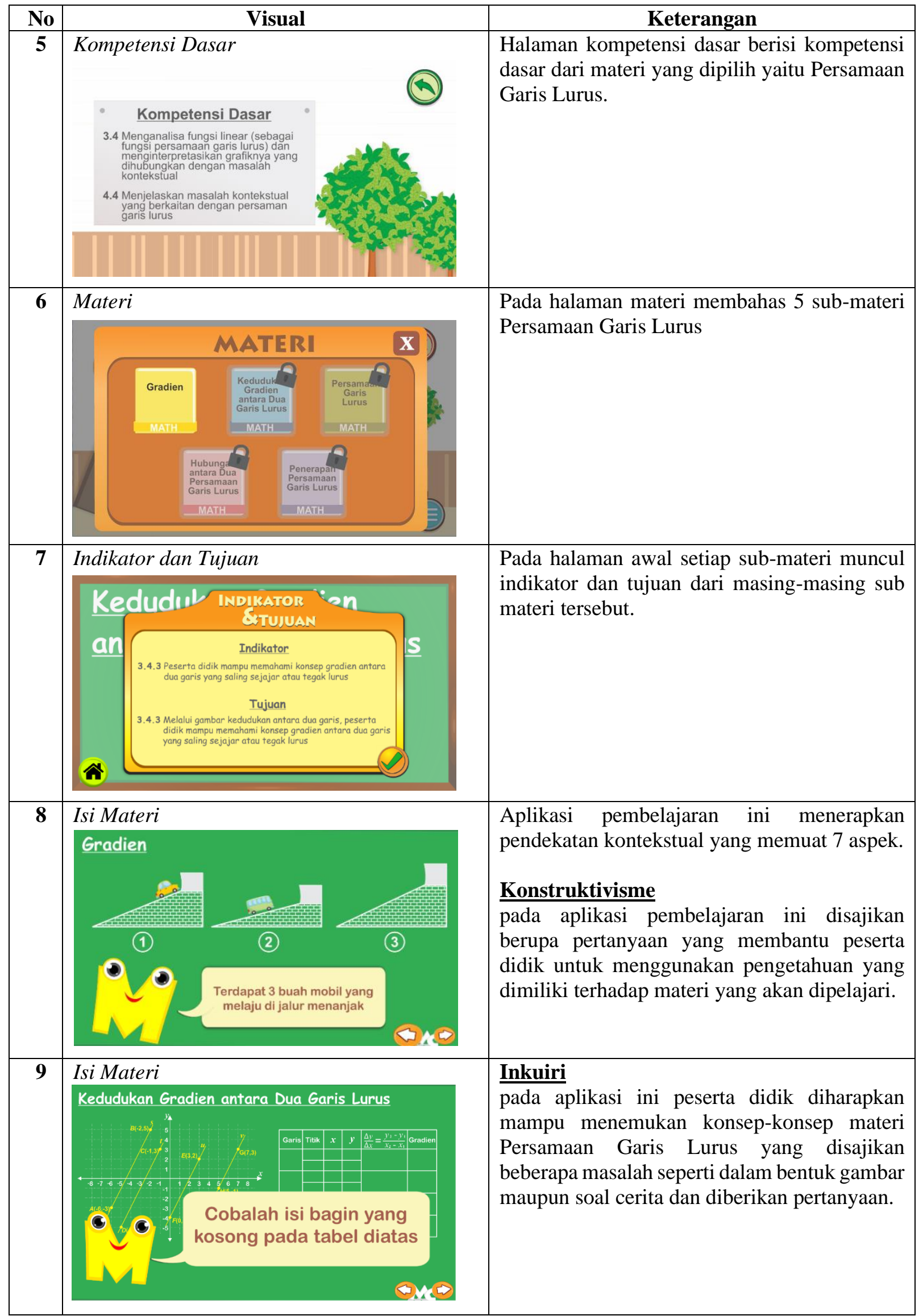




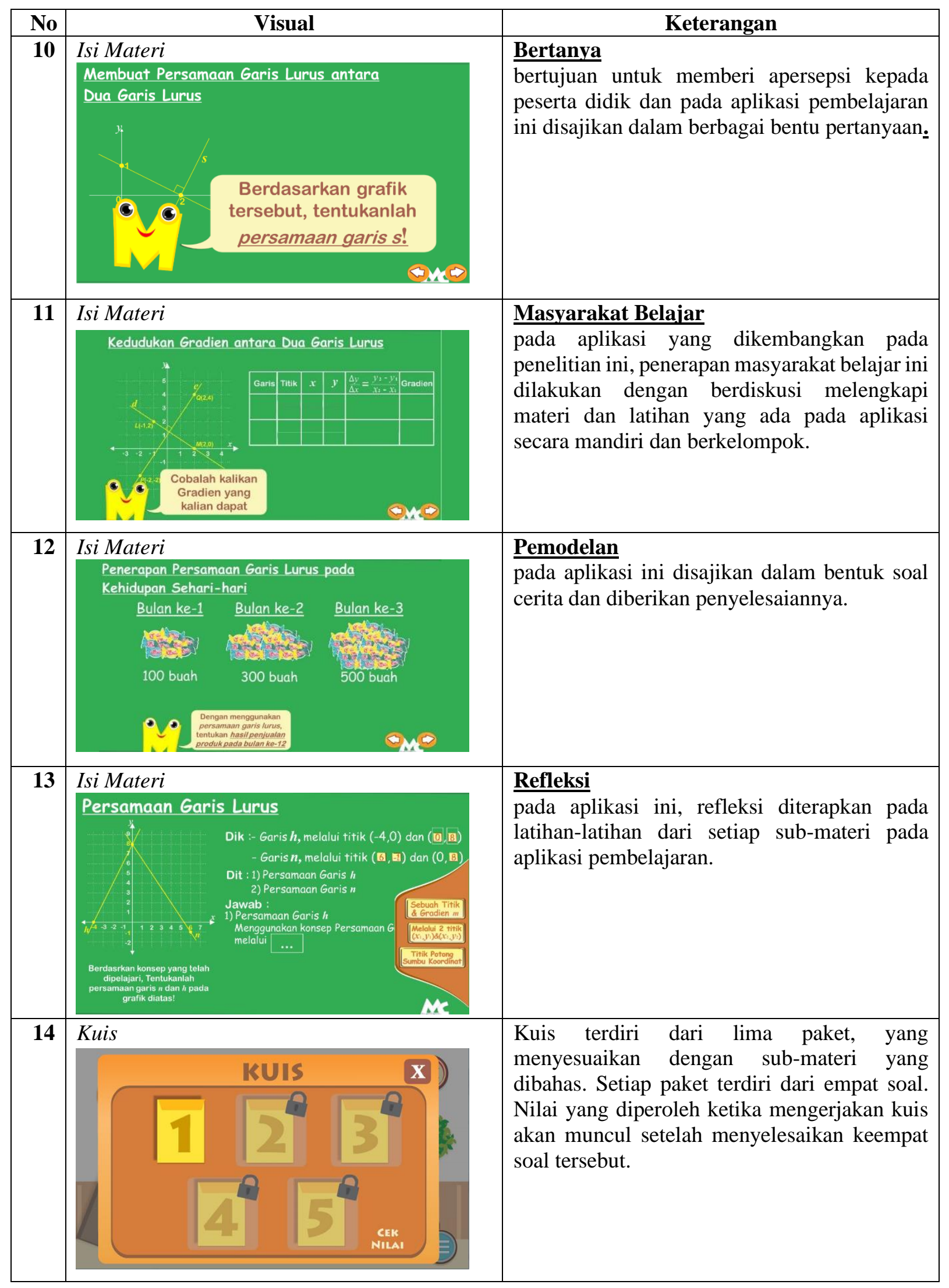


Pengembangan Aplikasi Pembelajaran Matematika Berbasis Android Dengan Pendekatan Kontekstual Pada Materi Persamaan Garis Lurus Untuk Peserta Didik Kelas VIII, Makmuri, Dwi Antari Wijayanti, Ellis Salsabila, Rena Nur Fadillah

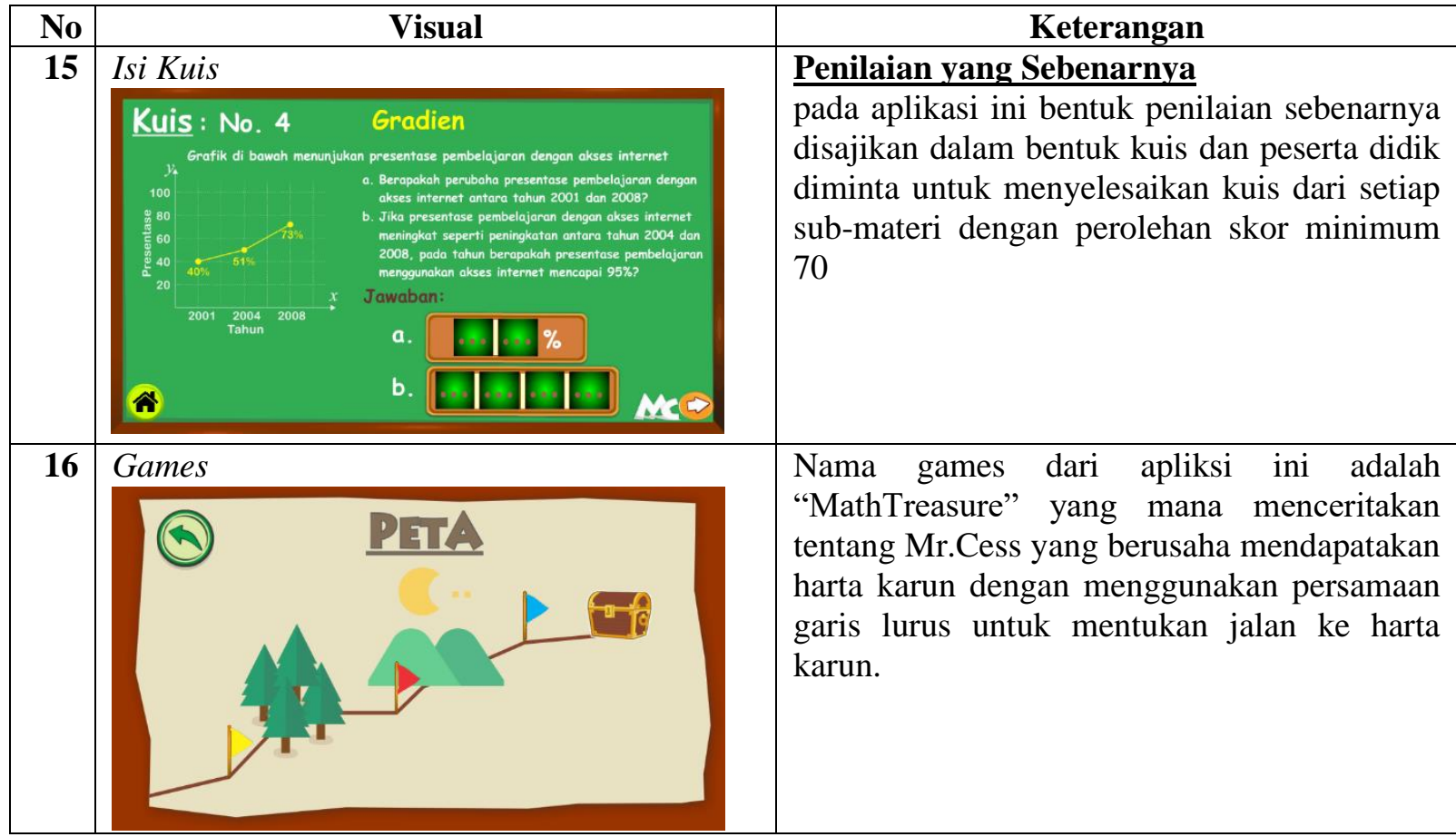

Hasil aplikasi pembelajaran matematika berbasis android yang tela di kembangkan kemudian divalidasi oleh ahli materi dan bahasa, ahli media, dan guru. Berikut ini disajikan hasil validasi media aplikasi pembelajaran berbasis andorid pada materi persamaan garis lurus:

Tabel 4. Validasi Ahli Media

\begin{tabular}{|c|l|c|c|c|c|}
\hline No & \multicolumn{1}{|c|}{ Aspek yang Diukur } & $\begin{array}{c}\text { Jumlah } \\
\text { Butir }\end{array}$ & $\begin{array}{c}\text { Jumlah } \\
\text { Skor }\end{array}$ & Persentase & Kriteria \\
\hline $\mathbf{1}$ & Aspek Kesesuaian Isi Aplikasi Pembelajaran & 8 & 67 & & \\
\cline { 1 - 3 } $\mathbf{2}$ & Aspek Teknis Penyajian & 8 & 67 & \multirow{2}{*}{$83.60 \%$} & $\begin{array}{c}\text { Sangat } \\
\text { Baik }\end{array}$ \\
\cline { 1 - 3 } 3 & Aspek Rekayasa Perangkat Lunak & 5 & 43 & & \\
\hline
\end{tabular}

Berdasarkan penilaian yang dilakukan oleh ahli media terkait aplikas pembelajaran berbasis android yang dikembangkan, memperoleh persentase sebesar $83.60 \%$ hal ini berarti "Sangat Baik" sehingga aplikasi pembelajaran berbasis android ini sudah layak uji coba lapangan. Selanjutnya disajikan tabel hasil validasi materi dan bahasa yang dilakukan oleh dua dosen validator, dengan hasil sebagai berikut:

Tabel 5. Validasi Ahli Materi dan Bahasa

\begin{tabular}{|c|l|c|c|c|c|}
\hline No. & Aspek yang Diukur & $\begin{array}{c}\text { Jumlah } \\
\text { Butir }\end{array}$ & $\begin{array}{c}\text { Jumlah } \\
\text { Skor }\end{array}$ & Persentase & Kriteria \\
\hline $\mathbf{1}$ & Aspek Isi Aplikasi Pembelajaran & 8 & 67 & & \\
\cline { 1 - 3 } $\mathbf{2}$ & $\begin{array}{l}\text { Aspek Sistematika Isi Aplikasi } \\
\text { Pembelajaran }\end{array}$ & 10 & 76 & \multirow{2}{*}{$78.06 \%$} & \multirow{2}{*}{ Baik } \\
\cline { 1 - 3 } $\mathbf{3}$ & Aspek Cakupan Isi Materi & 10 & 75 & & \\
\cline { 1 - 3 } $\mathbf{4}$ & Aspek Pendekatan Kontekstual & 4 & 31 & & \\
\cline { 1 - 3 } & Aspek Bahasa & 4 & 32 & & \\
\end{tabular}


Hasil penilaian yang dilakukan oleh ahli materi dan bahasa terkait aplikas pembelajaran berbasis android yang dikembangkan, memperoleh hasil 78.06\% yang berarti "Baik" sehingga aplikasi pembelajaran berbasis android ini sudah layak uji coba lapangan. Lebih lanjut, berdasarkan penilaian yang dilakukan oleh guru terkait aplikas pembelajaran berbasis android yang dikembangkan, memperoleh hasil $86.25 \%$ yang berarti "Sangat Baik" sehingga aplikasi pembelajaran berbasis android ini sudah layak uji coba kepada peserta didik. Hasil penilaian yang diberikan oleh guru disajikan pada tabel 6.

Tabel 6. Validasi Guru

\begin{tabular}{|c|c|c|c|c|c|}
\hline No. & Aspek yang Diukur & $\begin{array}{c}\text { Jumlah } \\
\text { Butir }\end{array}$ & $\begin{array}{l}\text { Jumlah } \\
\text { Skor }\end{array}$ & Persentase & Kriteria \\
\hline 1 & $\begin{array}{l}\text { Aspek Isi Aplikasi } \\
\text { Pembelajaran }\end{array}$ & 8 & 32 & \multirow{6}{*}{$86.25 \%$} & \multirow{6}{*}{$\begin{array}{l}\text { Sangat } \\
\text { Baik }\end{array}$} \\
\hline 2 & $\begin{array}{l}\text { Aspek Sistematika Isi } \\
\text { Aplikasi Pembelajaran }\end{array}$ & 10 & 44 & & \\
\hline 3 & $\begin{array}{l}\text { Aspek Cakupan Isi } \\
\text { Materi }\end{array}$ & 10 & 40 & & \\
\hline 4 & $\begin{array}{l}\text { Aspek Pendekatan } \\
\text { Kontekstual }\end{array}$ & 4 & 19 & & \\
\hline 5 & Teknis Penyajian Media & 12 & 56 & & \\
\hline 6 & Kebahasaan & 4 & 16 & & \\
\hline
\end{tabular}

Setelah aplikasi pembelajaran tersebut dinyatakan valid, maka peneliti melakukan uji coba produk ke dalam skala kecil dengan 10 orang peserta didik di kelas VIII. B dengan hasil sebagai berikut:

Tabel 7. Hasil Uji Coba Kelompok Kecil

\begin{tabular}{|c|l|c|c|c|c|}
\hline No. & \multicolumn{1}{|c|}{ Aspek } & $\begin{array}{c}\text { Jumlah } \\
\text { Butir }\end{array}$ & $\begin{array}{c}\text { Jumlah } \\
\text { Skor }\end{array}$ & Persentase & Kriteria \\
\hline $\mathbf{1}$ & $\begin{array}{l}\text { Kesesuaian Isi Media } \\
\text { Pembelajaran }\end{array}$ & 11 & 103 & & \\
\cline { 1 - 4 } $\mathbf{2}$ & Teknis Penyajian Media & 8 & 78 & \multirow{2}{*}{$93.20 \%$} & $\begin{array}{c}\text { Sangat } \\
\text { Baik }\end{array}$ \\
\cline { 1 - 4 } $\mathbf{3}$ & $\begin{array}{l}\text { Rekayasa Perangkat } \\
\text { Lunak }\end{array}$ & 4 & 37 & & \\
\cline { 1 - 3 } $\mathbf{4}$ & Kebahasaan & 2 & 17 & & \\
\hline
\end{tabular}

Berdasarkan respon yang diberikan peserta didik terikait aplikas pembelajaran berbasis android yang dikembangkan, memperoleh persentase sebesar 93.20\% hal ini berarti "Sangat Baik" sehingga aplikasi pembelajaran berbasis android ini mendapatkan respon yang baik dari peserta didik. Uji coba kelompok besar dilakukan untuk menilai kembali respon peserta didik teradap aplikas pembelajaran berbasis android yang telah direvisi oleh para ahli dan tambahn saran dari uji coba sebelumnya. Hasil uji coba yang dilakukan kepada 34 pesera didik di kelas VIII.A yaitu: 
Tabel 8. Hasil Uji Coba Kelompok Besar

\begin{tabular}{|c|c|c|c|c|c|}
\hline No & Aspek & $\begin{array}{l}\text { Jumlah } \\
\text { Butir }\end{array}$ & $\begin{array}{l}\text { Jumlah } \\
\text { Skor }\end{array}$ & Persentase & Kriteria \\
\hline 1 & $\begin{array}{l}\text { Kesesuaian Isi Media } \\
\text { Pembelajaran }\end{array}$ & 11 & 355 & \multirow{4}{*}{$95.65 \%$} & \multirow{4}{*}{$\begin{array}{l}\text { Sangat } \\
\text { Baik }\end{array}$} \\
\hline 2 & Teknis Penyajian Media & 8 & 261 & & \\
\hline 3 & $\begin{array}{l}\text { Rekayasa Perangkat } \\
\text { Lunak }\end{array}$ & 4 & 132 & & \\
\hline 4 & Kebahasaan & 2 & 65 & & \\
\hline
\end{tabular}

Berdasarkan respon yang diberikan peserta didik terkait aplikas pembelajaran berbasis android yang dikembangkan, memperoleh persentase sebesar $95.65 \%$ hal ini berarti "Sangat Baik" sehingga aplikasi pembelajaran berbasis android dapat dikembangakn kembali menjadi salah satu sumber belajar peserta didik.

\section{KESIMPULAN}

Berdasarkan hasil penelitian pengembangan berupa aplikasi pembelajaran matematika berbasis android pada materi persamaan garis lurus dengan menggunakan pendekatan kontekstual, maka dapat disimpulkan bahwa aplikasi pembelajaran berbasis android dapat dikembangkan secara layak sebagi salah satu sumber belajar matematika, khususnya pada materi Persamaan Garis Lurus. Hal ini didukung melalui respon yang diberikan peserta didik terkait aplikasi pembelajaran berbasis android yang dikembangkan, memperoleh persentase sebesar $95.65 \%$ dan ini berarti aplikasi pembelajaran berbasis android dapat dikembangakn kembali menjadi salah satu sumber belajar peserta didik. Selain itu aplikasi pembelajaran yang dikembangkan juga mendapat respon yang baik dari peserta didik karena penggunaan aplikasi ini membantu mereka dalam mempelajari materi dengan tampilan yang cukup komunikatif dan modern sehingga menjadi daya tarik bagi peserta didik dalam belajar materi Persamaan Garis Lurus.

Berdasarkan hasil penelitian yang telah dilakukan, terdapat beberapa saran sebagai berikut: 1) Penelitian dan pengembangan media pembelajaran berupa aplikasi pembelajaran matematika berbasis android pada materi persamaan garis lurus dengan menggunakan pendekatan kontekstual dapat dilanjutkan hingga tahap implementasi dan evaluasi pada penelitian selanjutnya, sehingga efektivitas media yang dikembangkan dapat terlihat, karena telah dilakukan implementasi kepada peserta didik dan 2) Penelitian selanjutnya dapat lebih menekankan lagi pendeketan yang akan digunakan pada aplikasi pembelajaran berbasis android agar lebih tersurat/ jelas lagi sintaksnya.

\section{UCAPAN TERIMA KASIH}

Pada kesempatan ini, penulis mengucapkan terima kasih kepada pihak-pihak yang telah membantu dalam penulisan artikel ini, yaitu:

1. Bapak Tian Abdul Aziz, Ph. D, Bapak Aris Hadiyan Wijaksana, M. Pd dan Bapak Med Irzal, M. 
Kom selaku dosen validator media, dan materi dan Bahasa

2. Ibu Cony Devilita, S. Pd selaku guru matematika kelas VIII SMP Negeri 7

3. Farah Ayu Anandita dan Faundry A.M. selaku pembuat program aplikasi

4. Maskanur Rezky, Christine Elliana, Eka Yunita Rahayu selaku sahabat yang telah mendukung pembuatan aplikasi ini.

\section{REFERENSI}

Barnch, R. M. (2009). Instractional Design: The ADDIE Approach. New York Dordreacht Heidelberg London: Springer.

Borg, W. R., Gall , M., \& Gall., J. ( 2003). Educational Research: An Introduction. United States of America: Allyn \& Bacon.

Daryanto, \& Karim, S. (2017). Pembelajaran Abad 21. Yogyakarta: Penerbit Gava Media.

Gafur, A. (2003). Penerapan Konsep dan Prinsip Pembelajaran Kontekstual (Contextual Teaching and Learning) dan Desain Pesan Dalam Pengembangan Pembelajaran dan Bahan Ajar. Jurnal Cakrawala Pendidikan Vol. 22 No.3.

Komalasari, K. (2011). Pembelajaran Kontekstual: Konsep dan Aplikasi. Bandung: PT. Refika Aditama.

Mulyana, D., \& Islandscript. (2012). Aplikasi Pilihan Android. Jakarta: PT Elex Media Komputindo.

Nugroho, A. A., \& Purwati, H. (2015). Pengembangan Media Pembelajaran Matematika Berbasis Mobile Learning dengan Pendekatan Scientific. Jurnal Euclid Vol. 2 No.1Jurnal Euclid Vol. 2 No.1.

Nurseto, T. (2011). Membuat Media Pembelajaran Yang Menarik. Jurnal Ekonomi \& Pendidikan Vol. 8 No. 1 .

Reiser, A. R. (2001). A History of Instructional Design and Technology: Part I: A History of Instructional Media. Jurnal Educational Technology Research and Development, vol. 49 No. 1.

Safaat, N. (2015). Android: Pemrogaman Aplikasi Mobile Smartphone dan Tablet PC Berbasis Android. Bandung: Informatika Bandung.

Setyadi, D. (2017). Pengembangan Mobile Learning Berbasis Android Sebagai Sarana Berlatih Mengerjakan Soal Matematika. Jurnal Satya Widya Vol. 33 No. 2.

Sudiono, E. (2017 ). Analisis Kesalahan dalam Menyelesaikan Soal Matematika Materi Persamaan Garis Lurus Berasarkan Analisis Newman. UNION: Jurnal Pendidikan Matematik, Vol. 5 No. 3. Sugiyono. (2013). Metode Penelitian Pendidikan: Pendekantan Kuantitatif, Kualitatif, dan $R \& D$. Bandung: Alfabeta.

Sugiyono. (2015). Metode Penelitian \& Pengembangan: Research and Development. Bandung: Alfabeta.

Umam, K., Suryawati, \& Septiana, E. (2017). Identifikasi Kesulitan Siswa dalam Memahami Persamaan Garis Lurus di SMP Negeri 6 Banda Aceh. Jurnal Serambi Akademica Vol. 5 No. 2. 